\title{
Andrzej Muszala, Józef Binnebesel, Piotr Krakowiak, Marek Krobicki (red.), Dolentium Hominum. Duchowni $i$ świeccy wobec ludzkiego cierpienia, Bonifratrzy, Kraków 2011, ss. 440.
}

Na rynku wydawniczym ukazała się niezwykła publikacja. Ową niezwykłość ująć można w czterech kategoriach. Kwestia pierwsza, chyba najistotniejsza, to treść publikacji. Jeden z recenzentów niniejszej książki, ks prof. Jarosław Michalski, pisze: „Niniejsza praca wpisuje się w nurt publikacji niezwykle dziś potrzebnych i cennych, znakomicie, bowiem - z poszanowaniem pluralizmu kulturowego i światopoglądowego, a także różnych systemów wartości - wypełnia lukę w zakresie holistycznego spojrzenia na ludzkie cierpienie, sposób reagowania oraz niesienia pomocy cierpiącym”. Redaktorzy z dużym znawstwem zebrali teksty można rzec niezwykłych ludzi. Wśród autorów znajdziemy Jana Pawła II, kard. Josepha Ratzingera, kard. Fiorenzo Angelino i Angelo Sodano oraz wiele innych znakomitości tak z hierarchii Kościoła, jak i nauki. W zebranych tekstach widać wyraźnie troskę kościoła o osoby najsłabsze bez względu na rodzaj i zakres owej słabości oraz wyznanie. Przebija z niej duch św. Jana Bożego, gdzie bracia Bonifratrzy od setek lat sprawują opiekę bez podziałów rasowych i wyznaniowych nad chorymi i potrzebującymi.

Kwestia kolejna, co zauważa drugi z recenzentów, ks. prof. Tadeusz Biesaga, to upowszechnienie ważnego a w Polsce prawie zupełnie nieznanego wydawanego przez Pontificio Consiglio della Pastorale per gli Operatori Sanitari - Dolentium Hominum czasopisma „Dolentium Hominum” które „od ponad 25 lat publikuje teksty wybitnych autorytetów Kościoła katolickiego, a także artykuły naukowców i praktyków z różnych krajów świata, poświęcone problemom służby zdrowia, opieki i duszpasterstwa chorych. Pomysł wyboru ważniejszych publikacji z tego potężnego źródła i udostępnienia ich polskim zespołom duchownych i świeckich opiekujących się chorymi jest niezwykle cenny".

Trzecią kwestią świadczącą o niezwykłości publikacji jest jej uniwersalizm tak tematyczny, jak i odbiorczy. Uniwersalizm tematyczny odnosi się do ujęcia problemu cierpienia. Dobór tekstów ujmuje owo cierpienie nie tylko w kontekście etycznym i religijnym, ale również konkretnym, działaniowym, pokazując różnorakie pola troski nie tylko duszpasterskiej, ale lekarskiej, pielęgniarskiej i psychologicznej o chorego. Ujmując w ten sposób ową troskę, wskazywany jest również aspekt wolontariatu i owej samarytańskiej posługi chorym i cierpiącym. Uniwersalizm odbiorczy odnosi się zaś do potencjalnych czytelników książki. Zawarte w książce treści mogą 
stanowić wspaniałe uzupełnienie wiedzy praktyków sprawujących opiekę nad chorymi, lekarzy, pielęgniarek, psychologów, pedagogów, pracowników socjalnych, osób świeckich, jak i konsekrowanych, jak również studentów medycyny, pielęgniarstwa, psychologii, pedagogiki, socjologii, pracy socjalnej, wszystkich, którzy w pracy zawodowej jak i studiowaniu poruszają się w obrębie ludzkiego cierpienia, opieki i zaspakajania potrzeb. Publikacja ta to nie tylko swoisty przewodnik duchowy, ale również poradnik mądrych zasad w sprawowaniu opieki.

Czwarty aspekt, rzucający się od razu w oczy czytelnikowi to wydanie. Rzadko zdarza się znaleźć tak starannie i po prostu ładnie wydaną książkę. Reasumując wydaje się, iż na rynku ukazała się książka niezwykła, ważna dla tych, którym problemy bioetyczne towarzyszą zarówno w analizach naukowych, jak i w działaniach leczniczych i opiekuńczych.

Czestaw Kustra*

\section{Stanisław Glaz, Niektóre czynniki warunkujące przeżycia religijne mlodzieży studiującej, Wydawnictwo WAM, Wyższa Szkoła Filozoficzno-Pedagogiczna „Ignatianum”, Kraków 2009, ss. 136.}

Nakładem Wydawnictwa WAM oraz Wydawnictwa Wyższej Szkoły Filozoficzno-Pedagogicznej „Ignatianum” opublikowana została w 2009 roku praca Stanisława Głaza pod tytułem: Niektóre czynniki warunkujące przeżycia religijne młodzieży studiujacej. Jej autor jest profesorem Wyższej Szkoły Filozoficzno-Pedagogicznej „Ignatianum” w Krakowie, w której pełni funkcję kierownika Katedry Psychologii Ogólnej. W kręgu zainteresowań naukowych badacza znajdują się zagadnienia osobowości, jej struktury i rozwoju, a także problematyka doświadczeń religijnych i trudności przeżywanych przez człowieka w tych sferach. Stanisław Głaz jest autorem kilkudziesięciu książek i artykułów oraz twórcą kilku metod badawczych.

Jak podkreśla uczony, jego rozprawa ma charakter teoretyczno-empiryczny. Koncentrując się na zagadnieniu religijności i osobowości człowie$\mathrm{ka}$, podjął on próbę przedstawienia związku przeżyć religijnych z takimi wymiarami osobowości, jak sfera emocjonalno-uczuciowa, wartości, prze-

* Ks. dr hab. Czesław Kustra, prof. UMK, jest kierownikiem Katedry Teorii Opieki i Wychowania na Wydziale Nauk Pedagogicznych Uniwersytetu Mikołaja Kopernika w Toruniu. 